\title{
A Study of the Construction of Subject Service Platform in University Library with the Orientation of the Construction of Key Subjects
}

\author{
Xinyu Wang, Qingsong Zhang \\ library, \\ JiLin Agricultural University , \\ Changchun, China \\ Email: wangxinyu8303@126.com; Email: 1007738301@qq.com
}

Key words: academic services; disciplinary platform construction; digital library

\begin{abstract}
With the higher education shifting from the mode of extensive development which is aim at expanding school scale to the mode of intensive development which is centered on discipline construction and quality improvement, the disciplinary level, contribution and influence have become the core competitiveness of universities.It puts forward higher requests to the service duty of high school library, and compells the digital library to respond faster, to make and adjust the development plan in time, and to realize the coordinated development of technology, resources and services. Consequently, it is more urgent to constructe the library discipline service platform.
\end{abstract}

\section{Introduction}

Because of the obvious characteristics of subjects and majors of the universities, the university library service is an important part of adapting to the subject construction and improving the level of scientific research, which is the long-term development trend of university library services. The subject librarians system in Chinese universities exited for more than ten years. During this period, the communication between the libraries and the teachers and students has been strengthened. The libraries has made further improvement in collection construction optimization, understanding of user needs, promotion of resources and services, user training, quality reference and other services. However, today, in the information environment and the changing needs of the users, there are still many problems in the subject service in the majority of our universities, such as poor communication, backward service and the lack of enthusiasm. Therefore, the problems are, which the university libraries should be considered profoundly: how to adapt to the new situation, how to innovate the means of subject services, how to develop more services to meet the individual needs of users, how to more fully utilize library resources and services.

\section{The Necessity for the University Libraries in Establishing the Subject Services}

The subject service is an extension of traditional library reference consultation, which is involved from the subject librarians to the users' research work or teaching environment (including the physical environment and network environment). Based on the document resources, it provides targeted information service to the users' research and work, which embodies the libraries' innovation and the personalized services ${ }^{[1]}$. The university libraries have the advantage of the information resources, human resources for services. Carrying out the subject services for the teachers and students can promote the development of the subject construction and the universities themselves.

\section{A. The subject service is the requirement of subject construction in universities}

The fundamental tasks of subject construction in universities are to concentrate on the discipline direction, to gather subject teams and to build subject bases. The Collection with 
disciplines and specialization and subject service offers a powerful support for the concise direction of the subjects in school. The libraries use knowledge as the mining tool, organize and process the information resources of the carriers both at home and abroad for a particular subject, through the analysis of their themes. It can result in gaining a direction of a subject. According to the current development status of this subject in school, the main research directions of the subject can be settled. For building an academic team, we have to ensure the concentration of the human resources of the researchers and the stability of the research topic. The information resource equipped by the libraries offers different subject services, which is able to help the academic researchers to master the research topics of different subjects ${ }^{[2]}$. In this way, their subject research can be consistent with the development trends, without the subject "drift" and subject marginalization. The libraries build a good academic environment and information environment, which is in favor of attracting and retaining talents with subject innovation. Gathering subject teams greatly supports the construction of subject base in the fields of documents, information, knowledge and services.

\section{B. The subject service is the requirement of the innovation and development of the university libraries}

The institution of the university libraries is an important part of the whole higher education. The reform of the traditional model of library service and to carry out subject services, on the one hand, can improve the utilization rate of document resources so that teachers and researchers can get the subject information of referential value from the libraries. While on the other hand, the application of subject services gives the librarians a much higher requirement for their comprehensive quality. Establishing the system of subject librarians and carrying out the subject services will help them to find the potentials of librarians, to show the initiation of the librarians, to stimulate their enthusiasm for work, which push the librarians to strengthen the business learning and master the skills of documentation and information services. The subject librarians practice the innovative subject information service by the way of providing the teachers and researchers with the further scientific and research consultation. These can effectively improve the academic status of the libraries and the librarians' self-image, creating a good social environment for the innovation and development of the libraries.

\section{The objectives and functional framework of building the subject service platform in the libraries}

\section{A. The overall objectives of building the subject service platform in the libraries}

Under the background of Web3.0, the development trend of the Internet is formed, based on the collection of the users' demands. The digital libraries are developed from the resource-oriented and technology-driven services to the current dominant phase of service. The model of the library services is transformed to the people-centered personalized information service ${ }^{[3]}$. The content of services are developed to the digital resources. And the service focus is transferred to the electronic of documents and information consulting services. Correspondingly, the construction of subject service platform in libraries must be based on the information needs of the users, aimed at meeting the information needs of the users and settling problems. It must be built on the basis of rich subject knowledge and information resources. Integrating effectively resources, technology, services and the users by the advanced information technology methods making the libraries upgraded from "the repository libraries" to "knowledge service ones". The design of the system must be based on the Internet mode, and have the openness and interactivity of a higher.

\section{B. Functional Framework}

The subject service platform, is divided into the following five functional modules.

The subject gateways: (1) the resource navigation: the classification mechanism of subjects is a must. According to a certain subject classification system, all the resources of various subjects in or out of the libraries should be organized and revealed. The secondary processing and restructuring of the resources by the librarians should be allowed, which makes the gradual establishment of the 
links among resources; (2) one-stop search: the searching system have to be able to retrieve all of the resources on the platform. The search results are presented and available on the platform. And the searching model will gradually transfer from the keyword search to semantic search ${ }^{[4]}$.

The referential consultation: (1) real-time advice and offline consultation: to support a variety of real-time embedded consulting tools, such as IM, MSN, QQ, etc., and also supports the offline consultative approaches like Email, web forms, etc.; (2) Knowledge base: to allow the librarians and users to add content, and have content control mechanisms, which is based on the subject knowledge; (3) Q\&A from the experts: an open Q \& A mechanism from the experts is to be established, so is a certain incentives, which involve more and more experts in subjects in the virtual service.

The information literacy training: (1) the training management: to publish all kinds of training information and training programs, to summarize the training statistics, and to collect training feedback; (2) the training registration: to provide training booking; (3) the self-training: to open online classes, to provide information literacy test system, to offer the simulated combat, to support submitting the job training, etc..

The personalized service: (1) personalized interface and retrieve: to allow the users to set the interface according to their preference, and to showing the users key words automatically according to the users' habits; (2) the Web2.0 services: to integrate Web2.0 tools and provide Web2.0 services, such as the customized RSS, Tag, etc.; (3) the mobile services: to support smart phones, tablet PCs and other mobile devices, and to offer the mobile applications and mobile services; (4) the embedded services: to support embedded users' personal information and to achieve the seamless docking with other information systems.

The back-stage management: (1) the systematic management: includes the management of users, management of system parameters and security management; (2) data management: includes the management of data resources, data quality control and statistics of data use; (3) service management: includes the service distribution, response time, the design of service processes, service process control, etc..

\section{The problems to be solved in the construction of subject service platform}

\section{A. Improving the degree of integration of subject service platform}

The subject service platform should be compatible with other functional modules of the libraries, where the users can move to the related functions. In this way, the services the libraries are integrated as a whole. At the same time, the related information should be integrated between the subject service platform and the management system of the relevant departments in school, which allows the information to be mutually affected, cooperatively established and shared. The higher the degree of integration of subject service platform, the better experience will be given to the users, and the more favorable it will get to the subject service platform ${ }^{[5]}$.

\section{B. The sustainability of the development and construction of subject service platform}

The development of subject service platform is relative and progressing. The development and construction of subject service platform of a certain period are undergone according to the then disciplines and demands of subject services. With the development of information technology and the changes in the concept of subject services, at different times, the fields, depth and methods of the subject services all changes. This leads to the different needs for the functions of subject service platform. Therefore, the subject service platform needs to be sustainable with the development of demand subject services in libraries.

\section{Improving the scalability of subject service platform}

The development and construction of subject service platform should take its scalability into deep consideration. With the changing needs of the subject services and the service target, the platform should be extended to the services of some new subjects, or integrated with more resources and services of scalability in the existing modules. It is aimed at meeting the individual 
requirements of the subject services and their service targets in school, and at the same time, playing and showing fully the characteristics the subject services.

\section{Conclusion}

The subject service platform developed by the university itself or outsourced will become the main developmental direction of the future construction of subject service platform.

Whatever it is developed by the university itself, or outsourced, the key problems need to be settled, that is, improve the degree of integration of the platform, the sustainability of its development and construction, and its scalability.

\section{Acknowledgements}

This paper is the research finding of the 12th Five Year Plan of education science in Jilin Province "The construction and practice of support platform of universities' library rescourse and service facing to the construction of key disciplines" in the year of 2015 (Item Number: GH150212) and the research project of National Agricultural Literature Information Center of CALIS "The deep integration and further research of the library resources under the background of Big Data" in the year of 2015 (Item Number: 2015019)

\section{References}

[1] Zheng Feng. Study on the Construction of University Library Subject Service Platform, [J]. Researches In Library Science, 2012 (17): 41-44.

[2] Peng Li. Design and implementation of a one-stop discipline service platform based on Moodle, [J]. Journal of The Sichuan Society for Library Science, 2013 (3): 54-57.

[3] Yang Yong. On the Construction of Self-discipline knowledge Service Platform of University Library, [J]. Library, 2012(6):136-137.

[4] Zheng Huiling. Design and Practice of the University Library discipline services platform based on Web, [J]. Information Science, 2008 (12).

[5] Yang Hualing. On the Construction of the University Library discipline services platform based onSNS, [J]. Library and Information, 2012(3):104-106. 